\title{
Hepatitis C core antigen: a simple predictive marker for treatment response to the new direct-acting antiviral drugs in chronic HCV Egyptian patients
}

Asmaa M. Elbrolosy ${ }^{1 *}$ (D, Moamena S. Elhamouly ${ }^{2}$, Emad M. Eed ${ }^{1}$, Gamalat A. El Gedawy ${ }^{3}$, Mai Abozeid ${ }^{4}$ and Naglaa S. Elabd ${ }^{2}$

\begin{abstract}
Background: Successful eradication of hepatitis $\mathrm{C}$ virus $(\mathrm{HCV})$ has great impact on the prognosis of HCV-related complications and the associated mortality. The development of the new direct-acting antiviral drugs (DAAs) has revolutionized the treatment of HCV infection. HCV core antigen (HCVCAg) is a recently developed marker that displayed a good correlation with HCV RNA assays. Our main objectives were to correlate between serum levels of HCVcAg and HCV RNA loads in chronic HCV patients as well as to explore the potential value of HCVcAg assay in predicting treatment response to the new DAAs. The study enrolled a total of 280 chronic HCV-infected patients scheduled to start the new regimen for treatment of chronic HCV by all-oral, interferon-free DAAs. According to the viral load, the studied individuals were arranged into three groups corresponding to mild, moderate, and sever viremia. Serum level of HCVCAg was determined by ELISA technique and HCV RNA viral loads were quantified using the real-time PCR system. The assays were performed three times for all participants: prior to initiation of treatment, at the end of treatment (week 12), and 3 months post-treatment cessation (week 24).
\end{abstract}

Results: A statistically significant difference between HCV RNA and HCVCAg baseline levels among different viremia groups was detected $(P<0.001)$. There was a significant positive correlation between HCV RNA and HCVcAg baseline values among all the studied cases $(P<0.05)$ with a correlation coefficient of $0.752,0.976$, and 1.00 respectively for mild, moderate, and severe viremia groups. 92.9\% (260/280) of the studied patients achieved sustained virologic response, 3.6\% (10/280) were non-responders, and 3.6\% (10/280) had recurrent viremia/relapse as regards RT-PCR results.

Conclusion: HCVCAg is a promising alternative to HCV RNA assay. The ELISAs for HCVCAg proved excellent correlations with HCV RNA levels. Moreover, HCVCAg can be introduced as a simple and highly specific tool for monitoring the new DAA regimens particularly in low-resource settings.

Keywords: HCV core antigen, HCV RNA assay, New direct-acting antiviral drugs

\footnotetext{
* Correspondence: asmaaelbrolosy@yahoo.com

${ }^{1}$ Department of Medical Microbiology and Immunology, Faculty of Medicine,

Menoufia University, Shibin El Kom, Egypt

Full list of author information is available at the end of the article
}

Springer Open
๑) The Author(s). 2021 Open Access This article is licensed under a Creative Commons Attribution 4.0 International License, which permits use, sharing, adaptation, distribution and reproduction in any medium or format, as long as you give appropriate credit to the original author(s) and the source, provide a link to the Creative Commons licence, and indicate if changes were made. The images or other third party material in this article are included in the article's Creative Commons licence, unless indicated otherwise in a credit line to the material. If material is not included in the article's Creative Commons licence and your intended use is not permitted by statutory regulation or exceeds the permitted use, you will need to obtain permission directly from the copyright holder. To view a copy of this licence, visit http://creativecommons.org/licenses/by/4.0/. 


\section{Background}

The prevalence of HCV infection varies significantly all over the world. Treatment and monitoring of HCV infection are of great concern, especially in developing countries [1]. The highest prevalence of $\mathrm{HCV}$ in the world occurs in Egypt with estimates higher than 10\% among the general population. There are approximately 3.7 million persons in Egypt that have chronic HCV infection in 2015 [2].

In clinical practice, serological detection of anti-HCV antibodies is usually used for diagnosis of HCV infection. However, most assays are not able to distinguish patients with an ongoing active infection from those who have spontaneously cleared the virus [3]. Sometimes, there is a long seronegative interval throughout the course of $\mathrm{HCV}$ infection during which anti-HCV antibodies are undetectable. Immunosuppression may result in an insufficient antibody response as well. Therefore, anti-HCV assays still need additional confirmation [4].

Nucleic acid-based techniques for HCV RNA are currently used to confirm the diagnosis of $\mathrm{HCV}$ infection and to monitor the antiviral therapy because of their high specificity and sensitivity. However, the complexity and cost of such molecular diagnostics can constrain their use in low-resourced settings [5]. Likewise, cheaper and simple diagnostic tools and follow-up algorithms are in urgent need to enhance the global efforts for HCV eradication by the year 2030 particularly in low- and middle-income countries [6].

The HCV core antigen (HCVcAg) is a $21-\mathrm{kDa}$ structural phosphoprotein of the HCV capsid and comprising the first 191 amino acids of the viral polyprotein. Hepatitis $\mathrm{C}$ virus core antigen is highly conserved across $\mathrm{HCV}$ genotypes. It exists in both complete virions and RNA-free core protein structures [5]. During viral assembly, HCVcAg is released into the plasma/serum and can be detected earlier than antibodies during the course of HCV infection. Recently, less-expensive and timeconsuming immunoassay techniques for detecting HCVcAg have become available [7].

Viral kinetics of HCV no longer predict treatment duration or outcome; consequently, there is no longer value for repeated measurement of HCV RNA load. There is however great evidence that the amount of $\mathrm{HCV} c \mathrm{Ag}$ in the blood correlates well with the HCV RNA level. Thus, $\mathrm{HCV}$ cAg can identify patients with active HCV infection and is a surrogate marker for viral replication. Furthermore, HCVcAg assay may be superior to the current two-step diagnostic approach in terms of time and cost-saving benefits. The novel approach has also established its clinical utility in the screening of active $\mathrm{HCV}$ infections for anti-HCV antibody-positive individuals [8].
During the last decade, great interest has been focused on the development of direct-acting antiviral drugs (DAAs). These agents have the ability to block essential enzymes regulating $\mathrm{HCV}$ replication. Several new oral, interferon-free antiviral drugs were approved, representing an additional bonus of extension into pan-genotypic activity [9].

The proximate target of anti-HCV therapy is to achieve sustained virologic response (SVR)/virologic cure meaning that HCV RNA is undetectable for at least 12 weeks after cessation of therapy. In the year 2011, the FDA accepted SVR-12 as endpoint for future trials because HCV relapse usually occurs within the first 12 weeks after the end of treatment [10].

In the era of DAAs, many studies reported that HCVcAg could be employed as a simple marker to establish active infection, to initiate the requirement for treatment and then to evaluate viremia after completion of DAAs therapy as well [11]. The main objectives were to verify the utility $\mathrm{HCVcAg}$ assay in predicting treatment response to the new oral, interferon-free DAA regimen by comparing it with the established methods for quantification of HCV RNA.

\section{Methods}

This prospective study was carried out at the Department of Medical Microbiology and Immunology, in collaboration with Tropical Medicine Department, Faculty of Medicine, Menoufia University, and Department of Hepatology and Gastroenterology, National Liver Institute, Menoufia University, during the period from December 2018 to April 2020. The study involved 280 patients (100 females and 180 males). All patients were over 18 years of age, had compensated liver disease, and were diagnosed to have chronic $\mathrm{HCV}$ infection by enzyme-linked immunosorbent serum anti-HCV assay and confirmed by real-time PCR. All the recruited cases were scheduled to receive the new DAAs therapy for treatment of $\mathrm{HCV}$ infection as recommended by the Egyptian National Committee for Control of Viral Hepatitis $(\mathrm{NCCVH})$.

The included patients were prescribed sofosbuvir (SOF)/daclatasvir (DCV) (easy to treat) or SOF/DCV/ribavirin (RVN) (difficult to treat) according to the NCCV $\mathrm{H}$ as follows:

- Easy to treat group: Comprises treatment-naïve patients, total bilirubin $<1.2 \mathrm{mg} / \mathrm{dl}$, serum albumin $>$ $3.5 \mathrm{~g} / \mathrm{dl}$, INR $<1.2$, and platelet count $>150,000 /$ $\mathrm{mm}^{3}$

- Difficult to treat group: Comprises IFN-experienced patients, total bilirubin $\geq 1.2 \mathrm{mg} / \mathrm{dl}$, serum albumin (2.8-3.5 g/dl), INR (1.2-1.7), and platelet count of $50,000-150,000 / \mathrm{mm}^{3}$ 
Table 1 Baseline routine and specific laboratory investigations of the studied groups

\begin{tabular}{|c|c|c|c|c|c|}
\hline \multirow[t]{3}{*}{ Lab investigations } & \multicolumn{3}{|c|}{ Total cases $($ No. $=280$ ) } & \multirow[t]{3}{*}{ Test of significance } & \multirow[t]{3}{*}{$P$ value } \\
\hline & Group I (No. = 140) & Group II (No. $=80$ ) & Group III (No. = 60) & & \\
\hline & Mean \pm SD & Mean \pm SD & Mean \pm SD & & \\
\hline ALT (IU/ml) & $58.6 \pm 7.8$ & $75.0 \pm 20.6$ & $122.0 \pm 66.4$ & Kruskal-Wallis test $=17.6$ & $<0.001^{* *}$ \\
\hline AST $(I U / m l)$ & $44.1 \pm 13.3$ & $65.0 \pm 23.3$ & $114.2 \pm 67.6$ & Kruskal-Wallis test $=17.14$ & $<0.001^{* *}$ \\
\hline ALP (IU/ml) & $29.8 \pm 14.8$ & $75.1 \pm 24.4$ & $134.8 \pm 68.8$ & Kruskal-Wallis test $=21.24$ & $<0.001^{* *}$ \\
\hline GGT (IU/ml) & $12.7 \pm 7.5$ & $30.1 \pm 10.8$ & $63.3 \pm 12.1$ & Kruskal-Wallis test $=20.14$ & $<0.001^{* *}$ \\
\hline Total bilirubin (mg/dl) & $1.1 \pm 0.27$ & $1.2 \pm 0.84$ & $1.8 \pm 1.2$ & Kruskal-Wallis test $=0.73$ & 0.69 \\
\hline Albumin (g/dl) & $3.8 \pm 0.54$ & $3.7 \pm 0.39$ & $3.4 \pm 0.37$ & ANOVA test $=0.85$ & 0.44 \\
\hline PT (s) & $14.5 \pm 2.1$ & $14.5 \pm 1.6$ & $14.9 \pm 2.2$ & ANOVA test $=0.08$ & 0.92 \\
\hline PT concentration (\%) & $86.3 \pm 19.5$ & $86.8 \pm 9.5$ & $84.9 \pm 13.9$ & ANOVA test $=0.05$ & 0.95 \\
\hline INR & $1.2 \pm 0.17$ & $1.2 \pm 0.15$ & $1.2 \pm 0.18$ & ANOVA test $=0.09$ & 0.91 \\
\hline $\mathbf{H b}(\mathrm{gm} / \mathrm{dl})$ & $13.6 \pm 1.7$ & $13.6 \pm 1.3$ & $12.8 \pm 2.8$ & ANOVA test $=0.41$ & 0.67 \\
\hline $\operatorname{PLT}\left(X 10^{3} / \mathrm{mm}\right)$ & $186.2 \pm 48.3$ & $189.9 \pm 57.4$ & $157.0 \pm 62.6$ & Kruskal-Wallis test $=1.60$ & 0.45 \\
\hline Glucose (mg/dl) & $92.9 \pm 30.5$ & $90.1 \pm 25.6$ & $98.2 \pm 36.9$ & Kruskal-Wallis test $=0.16$ & 0.92 \\
\hline Creatinine (mg/dl) & $0.81 \pm 0.12$ & $0.81 \pm 0.09$ & $0.83 \pm 0.13$ & ANOVA test $=0.88$ & 0.92 \\
\hline Urea $(\mathrm{mg} / \mathrm{dl})$ & $35.0 \pm 10.9$ & $44.5 \pm 9.1$ & $39.5 \pm 11.3$ & ANOVA test $=2.08$ & 0.15 \\
\hline
\end{tabular}

Exclusion criteria were determined as per the Supreme Council and National treatment programme of Hepatitis C updated Treatment Protocol December 2019 [12]. These included Child's C cirrhotic patients, platelet count less than $50,000 / \mathrm{mm}^{3}$, serum albumin $<2.8 \mathrm{~g} / \mathrm{dl}$, total serum bilirubin $>3 \mathrm{mg} / \mathrm{dl}$, INR $>1.7$, patients coinfected with HIV, hepatocellular carcinoma (HCC) except 6 months after intervention aiming at cure with no evidence of activity by dynamic imaging (CT or MRI), extra-hepatic malignancy except after 2 years of diseasefree interval, pregnancy or inability to use effective contraception, and inadequately controlled diabetes mellitus.

All patients had given informed consent about the study and ethical approval was provided by the Ethics Committee of Menoufia University which came in accordance with the ethical guidelines of the 2013 "Helsinki Declaration".

According to the $\mathrm{HCV}$ viral load, the studied patients were arranged into three groups: group I involved 140 patients with mild viremia $(<200,000 \mathrm{IU} / \mathrm{ml})$, group II involved 80 patients with moderate viremia (200,000:2, $000,000 \mathrm{IU} / \mathrm{ml}$ ), and group III involved 60 patients with severe viremia $(>2,000,000 \mathrm{IU} / \mathrm{ml})[13]$.

All patients were subjected to proper history taking and clinical examination. Laboratory investigations regarding complete blood picture, liver profile (including ALT, AST, ALP, GGT, serum albumin, total bilirubin, direct bilirubin, and INR), kidney function tests, and viral hepatitis markers for $\mathrm{HbsAg}$ and $\mathrm{HCV}$ antibodies were collected from each patient's file.

Blood samples were collected from all participants and then sera were stored at $-20{ }^{\circ} \mathrm{C}$ until assayed for quantitative estimation of HCV RNA and HCVcAg levels.

Quantitative estimation of HCV RNA level by real-time reverse transcription-polymerase chain reaction (RT-PCR)

The assay was done 3 times for each patient as follows: PCR-1, prior to initiation of treatment to ensure the diagnosis of $\mathrm{HCV}$ infection and to determine the

Table 2 Mean values of baseline levels for both HCV RNA (IU/ml) and HCVCAg (Peiu/ml) assays among the studied groups

\begin{tabular}{|c|c|c|c|c|c|c|}
\hline \multirow[t]{2}{*}{ Studied groups } & \multicolumn{6}{|l|}{ Baseline levels } \\
\hline & $\begin{array}{l}\text { HCV RNA serum level (IU/ml) } \\
\text { Mean } \pm \text { SD }\end{array}$ & $\begin{array}{l}\text { Kruskal- } \\
\text { Wallis test } \\
P \text { value }\end{array}$ & $\begin{array}{l}\text { Post hoc } \\
\text { test }\end{array}$ & $\begin{array}{l}\text { HCVcAg serum level (Peiu/ml) } \\
\text { Mean } \pm \text { SD }\end{array}$ & $\begin{array}{l}\text { ANOVA } \\
\text { test and } P \\
\text { value }\end{array}$ & $\begin{array}{l}\text { Post hoc } \\
\text { test }\end{array}$ \\
\hline Group I $(n=140)$ & $95648.1 \pm 50814.0$ & \multirow{3}{*}{$\begin{array}{l}\text { Test }=22.76 \\
P<0.001^{* *}\end{array}$} & \multirow{3}{*}{$\begin{array}{l}\mathrm{P} 1<0.001^{* *} \\
\mathrm{P} 2=0.001^{* *} \\
\mathrm{P} 3=0.002^{*}\end{array}$} & $1.4 \pm 0.35$ & \multirow{3}{*}{$\begin{array}{l}\text { Test }=69.69 \\
P<0.001^{* *}\end{array}$} & \multirow{3}{*}{$\begin{array}{l}\mathrm{P} 1=0.002^{*} \\
\mathrm{P} 2<0.001^{* *} \\
\mathrm{P} 3<0.001^{* *}\end{array}$} \\
\hline Group II $(n=80)$ & $1082313.0 \pm 558186.7$ & & & $2.6 \pm 0.68$ & & \\
\hline Group III $(n=60)$ & $4812067.8 \pm 1837006.9$ & & & $5.9 \pm 1.5$ & & \\
\hline
\end{tabular}


baseline viral load; PCR-2, at the end of treatment (week 12) to assess end of treatment response (ETR) [14]; and PCR-3, 3 months post-treatment cessation (week 24) as a follow-up step to assess sustained virologic response (SVR-12) [14].

\section{Procedure}

The procedure involved three main steps: HCV RNA extraction, conversion of HCV RNA to complementary DNA (Cdna), and amplification and detection of the amplified products. HCV RNA extraction was performed by using artus ${ }^{\oplus}$ HCV RG RT-PCR kit (Qiagen GmbH, Germany, Cat No. 4518263) according to the manufacturer's instructions. HCV levels were determined using the Rotor-Gene Q MDx (Rotor-Gene Q MDx, Qiagen, Germany) Light Cycler Real-Time PCR System using Rotor-Gene-3000 software version 6.0.23. An internal quality control serum was included during RT-PCR [15].

\section{HCVcAg assay}

$\mathrm{HCV}$ core antigen serum levels were measured by enzyme-linked immunosorbant assay according to the manufacturer's instructions (Sinogeneclon Co., Ltd, China). The concentration of HCVcAg in the samples was then determined by comparing the optical density (O.D.) of the samples to the standard curve. The assay was done at the same intervals of the PCR assay.

\section{Statistical analysis}

Statistical analysis was done using SPSS version 20. Continuous/numerical data were presented as mean \pm standard deviation (SD) and were compared by KruskalWallis test and ANOVA test. Categorical variables were shown as numbers (percentages) and were compared by Chi-square $\left(\chi^{2}\right)$ test. Linear regression analysis was applied to evaluate the association between $\mathrm{HCVcAg}$ and HCV RNA levels. The diagnostic performance of HCVcAg and HCV RNA in the prediction of SVR-12 was expressed as sensitivity, specificity, positive predictive value (PPV), negative predictive value (NPV), and area under the receiver operating characteristic (AUROC) curve. Statistical significance was set at $P$ value $<0.05$.

\section{Results}

Baseline routine and specific laboratory investigations of the studied groups are shown in Table 1. A highly significant statistical difference was recorded regarding serum ALT, AST, ALP, and GGT levels among the three studied viremia groups $(P<0.001)$. Other parameters revealed no significant difference $(P>0.05)$.

Baseline levels of both HCV RNA and HCVcAg assays were represented in Table 2 and Figs. 1 and 2. The

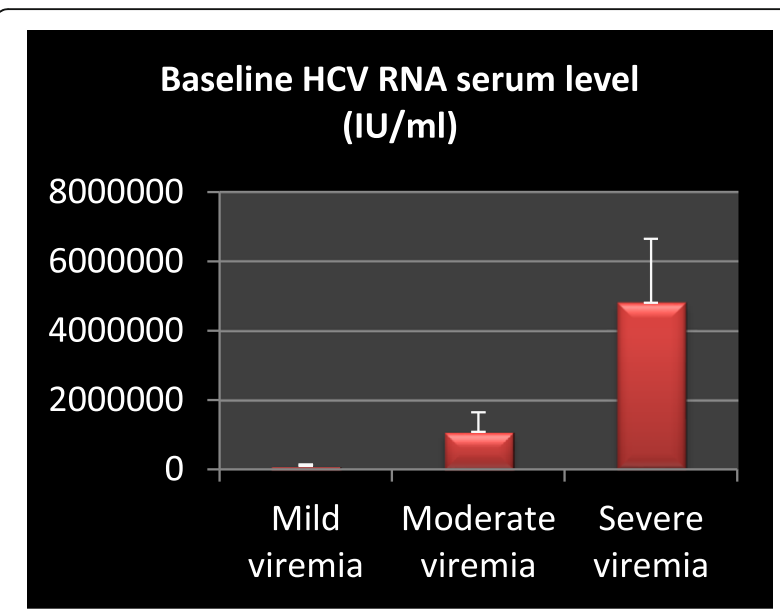

Fig. 1 Baseline HCV RNA levels (IU/mL)

recorded data denoted a statistically significant difference between the mean values of both HCV RNA and $\mathrm{HCV}$ cAg baseline levels among different viremia groups $(P<0.001)$. The level of $\mathrm{HCV} c A g$ was significantly higher in moderate viremia if compared with mild viremia $(P<0.002)$ and it was significantly higher in severe viremia if compared with moderate viremia $(P<$ $0.001)$.

Importantly, a significant positive correlation was detected between HCV RNA and HCVcAg baseline values among all the studied cases $(P<0.05)$ with a correlation coefficient of $0.752,0.976$, and 1.00 respectively for mild, moderate, and severe viremia groups as shown in Table 3 . The correlations of HCV RNA loads (IU/ml) with $\mathrm{HCV}$ cAg levels (Peiu/ml) including linear regression lines were illustrated in Fig. 3a-c.

For differentiation between mild and moderate viremia, $\mathrm{HCV}$ cAg proved sensitivity, specificity, PPV, NPV, and diagnostic accuracy of $87.5 \%, 85.7 \%, 77.8 \%$, $92.3 \%$, and $86.4 \%$ respectively when using a cutoff value

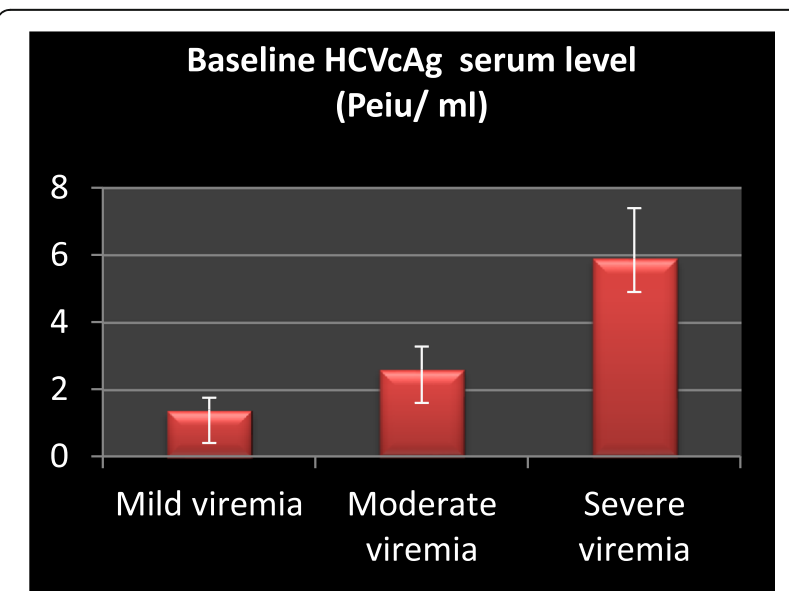

Fig. 2 Baseline HCVcAg levels (Peiu/mL) 
Table 3 Correlation between baseline levels of HCVcAg (Peiu/ml) and HCV RNA (IU/ml) assays among the studied groups

\begin{tabular}{|c|c|c|}
\hline \multirow[t]{2}{*}{ Baseline HCV RNA (IU/ml) } & \multicolumn{2}{|c|}{ Baseline HCVcAg (Peiu/ml) } \\
\hline & $r$ & $P$ value \\
\hline Group I: mild viremia group $($ No. $=140)$ & 0.752 & $0.002^{*}$ \\
\hline Group II: moderate viremia group $($ No. $=80$ ) & 0.976 & $<0.001^{* *}$ \\
\hline Group III: severe viremia group $($ No. $=60$ ) & 1.00 & $<0.001^{* *}$ \\
\hline
\end{tabular}

of 1.765 Peiu/ml. However, HCVcAg cutoff point of 3.42 Peiu/ml exhibited sensitivity, specificity, PPV, NPV, and diagnostic accuracy of $100 \%, 87.5 \%, 85.7 \%, 100 \%$, and 92.9\% respectively for differentiation between moderate and severe viremia (Table 4).

Regarding treatment response to the newly prescribed regimen of DAAs, $92.9 \%(260 / 280)$ of the studied cases achieved sustained virologic response (SVR-12), 3.6\%
(10/280) were non-responders with persistent viremia throughout the course of the study, and 3.6\% (10/280) had recurrent viremia/relapse after treatment cessations as proved by RT-PCR results (Table 5).

Among patients who achieved SVR (260/280), HCVcAg was $100 \%(260 / 260)$ undetectable at both the 12th and 24th weeks. For the patients who proved nonresponse to anti-HCV treatment, $\mathrm{HCVcAg}$ was

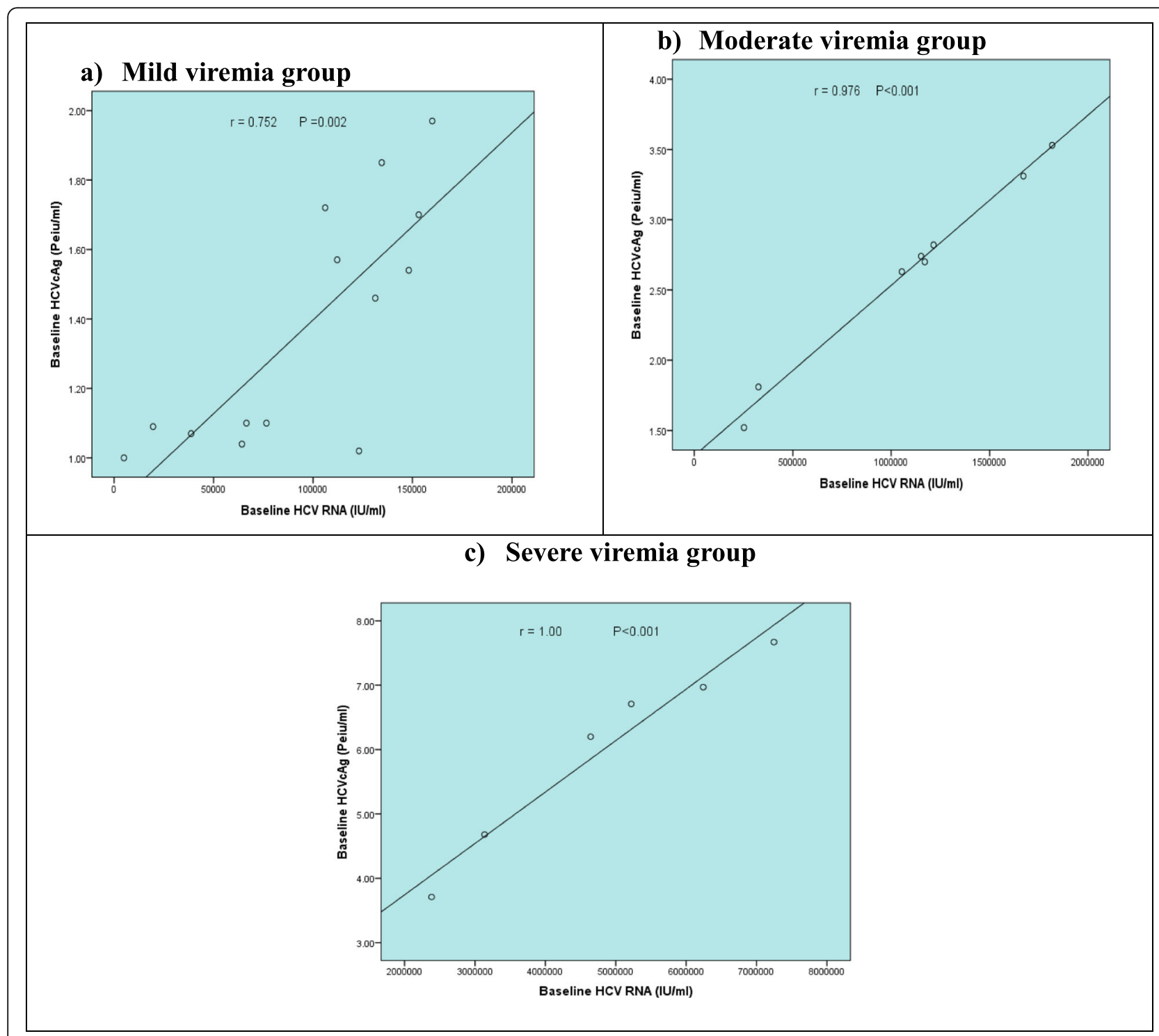

Fig. 3 a-c Correlation between baseline levels of HCVCAg (Peiu/ml) and HCV RNA (IU/ml) assays among the studied groups 
Table 4 HCVcAg cutoff for differentiation between mild and moderate viremia

\begin{tabular}{llllllll}
\hline & AUC & Cutoff point & Sensitivity & Specificity & PPV & NPV & Accuracy \\
\hline HCVcAg (Peiu/ml) & 0.929 & 1.765 & $87.5 \%$ & $85.7 \%$ & $77.8 \%$ & $92.3 \%$ & $86.4 \%$ \\
HCVcAg cutoff for differentiation between moderate and severe viremia & & & & \\
HCVcAg (Peiu/ml) & 1.00 & 3.42 & $100 \%$ & $87.5 \%$ & $85.7 \%$ & $100 \%$ & $92.9 \%$ \\
\hline
\end{tabular}

continuously detectable at both the 12th and 24th weeks. However, for patients who developed recurrent viremia/ relapse, $\mathrm{HCV}$ cAg was undetectable at the 12th week and again became detectable at the 24th week posttreatment initiation (Table 6).

The degree of agreement between HCV RNA and HCVcAg results at the 12th and 24th weeks was $100 \%$ (Table 7). For evaluation of $\mathrm{HCV}$ cAg assay performance in prediction of treatment response at the 12th and 24th weeks, HCVcAg proved sensitivity, specificity, PPV, NPV, and accuracy of $100 \%$ (Table 8 ).

\section{Discussion}

HCV infection is a serious public health issue. Early detection and treatment are imperative to prevent its transmission. Limitations of anti-HCV and HCV RNA detection have restricted their applications in clinical practice [16].

$\mathrm{HCV} c \mathrm{Ag}$ has been proposed as an indirect marker of viral replication [16]. Recently, many assays have been developed for both qualitative and quantitative $\mathrm{HCVcAg}$ estimation, such as enzyme immunoassays (EIAs) or chemiluminescent immunoassays with an excellent correlation between $\mathrm{HCV}$ Ag concentrations and $\mathrm{HCV}$ RNA levels. These quantitative $\mathrm{HCV}$ cAg assays became promising alternatives to $\mathrm{HCV}$ nucleic acid-based techniques $[17,18]$.

In the current study, 280 patients with chronic HCV infection have been enrolled and arranged into mild, moderate, and severe viremia groups according to their HCV viral load. All studied individuals were prescribed the new regimen of anti-HCV treatment which included the new oral, interferon-free DAAs. The main targets were to correlate between baseline levels of both $\mathrm{HCV}$ cAg and $\mathrm{HCV}$ viremic load and to assess the utility of HCVcAg testing in the era of DAAs.

The recorded data denoted a highly significant statistical difference between the baseline values of both $\mathrm{HCV}$
RNA and HCVcAg among different viremia groups $(P<$ 0.001). Furthermore, a significant positive correlation was detected between HCV RNA and HCVcAg baseline levels for all the studied cases $(P<0.05)$ (correlation coefficient; $r=0.752$ for mild viremia, $r=0.976$ for moderate viremia, and $r=1.00$ for severe viremia). These finding agreed with previous reports by Soliman et al., Park et al., and Kim et al. $[15,19,20]$ who confirmed excellent correlation to HCV RNA levels and that the kinetics of $\mathrm{HCVcAg}$ and viremia were almost similar. Thong et al. also postulated that in the overall cohort, HCVcAg levels significantly correlated with the corresponding HCV RNA levels $(r=0.889, P<0.001)$. The authors recommended $\mathrm{HCV}$ cAg testing to be used as an alternative to HCV RNA assays in resource-limited settings [21].

Other previous studies involving other HCV genotypes demonstrated that detection of $\mathrm{HCV}$ cAg in serum or plasma is useful as an indirect marker of $\mathrm{HCV}$ replication due to the excellent correlation between $\mathrm{HCVcAg}$ and HCV RNA concentrations. In addition, HCVcAg assays, which are easier to perform than reverse transcription-PCR, also save time and are less expensive. $\mathrm{HCV} c \mathrm{Ag}$ is used currently to monitor patients undergoing antiviral therapy and to determine the clinical efficacy of such treatment [22-24].

Being closely related to $\mathrm{HCV}$ RNA as proved in current results, the present study involved analytical data that may support the use of $\mathrm{HCV}$ cAg as a prognostic marker for disease activity among $\mathrm{HCV}$-infected patients and consequently to be implemented in clinical practice for the follow-up of treatment response. At a cutoff point of $1.765 \mathrm{Peiu} / \mathrm{ml}, \mathrm{HCV} \mathrm{cAg}$ was able to differentiate between mild and moderate viremia with sensitivity, specificity, PPV, NPV, and diagnostic accuracy of $87.5 \%$, $85.7 \%, 77.8 \%, 92.3 \%$, and $86.4 \%$, respectively. However, HCVcAg cutoff point of $3.42 \mathrm{Peiu} / \mathrm{ml}$ exhibited sensitivity, specificity, PPV, NPV, and diagnostic accuracy of

Table 5 Treatment outcomes among the studied groups according to RT-PCR results

\begin{tabular}{|c|c|c|c|c|c|c|c|c|c|}
\hline \multirow[t]{3}{*}{ Treatment outcomes } & \multicolumn{6}{|c|}{ Total cases $($ No. $=280)$} & \multirow{2}{*}{\multicolumn{2}{|c|}{$\begin{array}{l}\text { Total }(n= \\
280)\end{array}$}} & \multirow{3}{*}{$\begin{array}{l}X^{2} \text { test } \\
\text { and } P \\
\text {-value }\end{array}$} \\
\hline & \multicolumn{2}{|c|}{ Group I $(n=140)$, } & \multicolumn{2}{|c|}{ Group II $(n=80)$} & \multicolumn{2}{|c|}{ Group III $(n=60)$, } & & & \\
\hline & No. & $\%$ & No. & $\%$ & No. & $\%$ & No. & $\%$ & \\
\hline Responder/SVR (No. = 260) & 130 & 92.9 & 70 & 87.5 & 60 & 100 & 260 & 92.9 & Test $=3.56$ \\
\hline Non-responder $($ No. $=10)$ & 10 & 7.1 & 0 & 0.0 & 0 & 0.0 & 10 & 3.6 & \\
\hline Relapse (No. = 10) & 0 & 0.0 & 10 & 12.5 & 0 & 0.0 & 10 & 3.6 & \\
\hline
\end{tabular}


Table 6 HCVcAg at baseline, the 12th week, and the 24th week regarding treatment response

\begin{tabular}{|c|c|c|c|c|c|}
\hline \multirow{3}{*}{$\begin{array}{l}\text { Response of cases (No. = } \\
\text { 280) }\end{array}$} & \multicolumn{5}{|c|}{ HCVcAg (Peiu/ml) } \\
\hline & \multirow[t]{2}{*}{ Baseline } & \multicolumn{2}{|c|}{ At the 12th week } & \multicolumn{2}{|c|}{ At the 24th week } \\
\hline & & Detectable & Undetectable & Detectable & Undetectable \\
\hline Responder/SVR $($ No. $=260$ ) & $2.7 \pm 2.1$ & $00.0 \%$ & $260100 \%$ & $00.0 \%$ & $260100 \%$ \\
\hline Non-responder $($ No. $=10)$ & 1.7 & $10100 \%$ & $00.0 \%$ & $10100 \%$ & $00.0 \%$ \\
\hline Relapse (No. = 10) & 3.5 & $00.0 \%$ & $10100 \%$ & $10100 \%$ & $00.0 \%$ \\
\hline
\end{tabular}

$100 \%, 87.5 \%, 85.7 \%, 100 \%$, and $92.9 \%$ respectively for differentiation between moderate and sever viremia. In another study by Sayed et al., the Roc curve showed that the best cutoff point between mild viremia patients and moderate viremia was found $>2.3$ with a sensitivity of $81.25 \%$, specificity of $100.0 \%$, PPV of $100.0 \%$, and NPV of $88.9 \%$. While Roc curve for HCVcAg between moderate and severe viremia showed that the best cutoff point was > 4.2 with sensitivity of $87.5 \%$, specificity of $93.75 \%$, PPV of $87.5 \%$, and NPV of $93.7 \%$ [25].

The introduction of DAAs therapies has revolutionized the treatment response of $\mathrm{HCV}$. In this context, we explored the relevance of $\mathrm{HCVCAg}$ testing to evaluate the potential role in monitoring virologic response to the new regimen of protease inhibitor-based therapy. In the current work, 92.9\% (260/280) of the studied cases achieved sustained virologic response, 3.6\% (10/280) were non-responders with persistent viremia throughout the course of the study, and 3.6\% (10/280) had recurrent viremia/relapse after completing treatment as proved by RT-PCR results. These results were almost comparable to the rates reported by Nouh et al. (95.8\% of patients achieved SVR-12 and 4.2\% were non-responders) [26]. Rockstroh et al. also postulated that advances in the treatment of HCV infection with DAAs have demonstrated over $90 \%$ cure rates, as defined by the SVR- 12 . With these therapies, high SVR rates can be obtained regardless of viral genotype, degree of liver fibrosis, or previous treatment history in the majority of patient groups [27].

Regarding relapse, in this study $3.6 \%$ of the enrolled patients had a relapse/recurrent viremia as proved by RT-PCR results after 3 months from completing treatment with the DAA combination therapy. Other studies conducted by Wang et al. and Rutter et al. revealed that about $13 \%$ of cases had relapse 3 months after completing treatment regimen with DAAs. They suggested that relapsed cases are probably attributed to emergence of treatment resistance-associated variants with reduced replication fitness compared with the wild type virus. If these resistance-associated variants cannot be eliminated by the required combination regimen, strains with reduced replication fitness may persist in low concentration and may account for late relapses [16, 28].

Interestingly, HCVcAg was able to detect 100\% (260/ $260)$ of patients who achieved SVR-12, 100\% (10/10) of those who were non-responders, and $100 \%(10 / 10)$ of patients who developed recurrent viremia/relapse during

Table 7 Degree of agreement between HCV RNA and HCVCAg results at the 12th and 24th week among the studied groups

\begin{tabular}{|c|c|c|c|c|c|}
\hline \multicolumn{5}{|l|}{ HCV RNA at the 12th week } & \multirow[t]{2}{*}{ Tota } \\
\hline & & & Positive & Negative & \\
\hline \multirow[t]{4}{*}{ HCVcAg at the 12th week } & Positive & No. & 10 & 0 & 10 \\
\hline & & $\%$ (within HCV RNA at the 12th week) & 100.0 & .0 & 3.6 \\
\hline & Negative & No. & 0 & 270 & 270 \\
\hline & & \% (within HCV RNA 12th week) & .0 & 100.0 & 96.4 \\
\hline \multirow[t]{2}{*}{ Total } & & No. & 10 & 270 & 280 \\
\hline & & \% (within HCV RNA 12th week) & 100.0 & 100.0 & 100.0 \\
\hline \multicolumn{6}{|l|}{ HCV RNA at the 24th week } \\
\hline & & & Positive & Negative & \\
\hline \multirow[t]{4}{*}{ HCVcAg at the 24th week } & Positive & No. & 20 & 0 & 20 \\
\hline & & $\%$ (within HCV RNA at the 24th week) & 100.0 & .0 & 7.1 \\
\hline & Negative & No. & 0 & 260 & 260 \\
\hline & & $\%$ (within HCV RNA at the 24th week) & .0 & 100.0 & 92.9 \\
\hline \multirow[t]{2}{*}{ Total } & & No. & 20 & 260 & 280 \\
\hline & & $\%$ (within HCV RNA at the 24th week) & 100.0 & 100.0 & 100.0 \\
\hline
\end{tabular}


Table 8 Evaluation of HCVCAg assay performance in prediction of treatment response at the 12th and 24th week among the studied groups

\begin{tabular}{llllll}
\hline & Sensitivity & Specificity & PPV & NPV & Accuracy \\
\hline HCVcAg at the 12th week (Peiu/ml) & $100 \%$ & $100 \%$ & $100 \%$ & $100 \%$ & $100 \%$ \\
HCVcAg at the 24th week (Peiu/ml) & $100 \%$ & $100 \%$ & $100 \%$ & $100 \%$ & $100 \%$ \\
\hline
\end{tabular}

post-treatment follow-up (sensitivity, specificity, PPV, $\mathrm{NPV}$, and diagnostic accuracy of $100 \%$ in relation to PCR results). In the same field, Pischke et al. studied a group of patients who had received DAAs and concluded that early response to treatment could be assessed by the less-expensive $\mathrm{HCV}$ cAg assay with equal reliability as PCR testing; therefore, both assays allowed prediction of SVR-12 with the same accuracy [29]. Aghemo et al. also reported that concordance between the two tests in identifying patients who achieved SVR12 was almost perfect where $\mathrm{HCV}$ cAg identified $97 \%$ of these patients [30]. In their study about the clinical utility of $\mathrm{HCV} c \mathrm{Ag}$ assay in the monitoring of DAAs for chronic hepatitis $\mathrm{C}$, Lin et al. declared that the HCVcAg assay identified $99 \%$ of patients with SVR-12 and that both undetectability of serum HCVcAg and HCV RNA had a high positive predictive value at week 2 (98\% vs. 100\%) and at week 4 (97\% vs. 99\%) in predicting SVR-12 [8].

Regarding sensitivity and specificity of $\mathrm{HCVcAg}$ for assessment of post-treatment viremia, many studies were nearly parallel to our result; Arboledas et al. [31] reported that the sensitivity of $\mathrm{HCV}$ cAg test was $86.5 \%$ and Daniel et al. [32] showed $85.3 \%$ sensitivity. Meanwhile, Ergunay et al. [33] revealed $75.8 \%$ sensitivity. A group of studies recorded sensitivity of more than $90 \%$, ranging from 93.26 to $96.3 \%$ as documented by Kotb et al. and Demircili et al. [34, 35]. Miedouge et al. reported that HCVcAg sensitivity was 100\% [36].

In their studies, Kesli et al. and Demircili et al. [4, 35] showed results which were almost comparable to current results as regards specificity (100\%). Ergunay et al. [33] revealed 95.1\% specificity, while Miedouge et al. and Medici et al. respectively found $99.2 \%$ and $97.9 \%$ specificity for $\mathrm{HCVcAg}$ quantitative assays versus nucleic acid-based test [36, 37].

In the year 2018, the European Association for the Study of the Liver recommended that HCVcAg in serum or plasma is a marker of HCV replication that can be used instead of HCV RNA to diagnose acute or chronic HCV infection when HCV RNA assays are not available and/or not affordable. HCVcAg is an easy test with comparable sensitivity (> 90\%) and satisfactory correlation with the HCV RNA. Quantification of HCVcAg is to be suggested as an attractive alternative to these expensive and demanding measurements [14].

\section{Conclusions}

$\mathrm{HCV}$ cAg displayed excellent sensitivity and specificity for detection of pre-treatment and post-treatment viremia in chronic $\mathrm{HCV}$ patients. HCVcAg successfully identified patients who achieved SVR from those with failed response and/or relapse after receiving the newly prescribed regimen of DAAs and should be considered for inclusion in routine laboratory testing. The technical feasibility of HCVcAg in diagnosis and treatment monitoring should improve access to care in areas where HCV RNA testing is not or hardly available. $\mathrm{HCV}$ cAg proved strong correlation with $\mathrm{HCV}$ RNA levels at mild, moderate, and sever viremia. We acknowledge that the results were analyzed with a relatively small cohort; therefore, to implement a practical policy in real-life settings, studies with larger cohorts are a must.

\section{Abbreviations}

HCV: Hepatitis C virus; HCVcAg: Hepatitis C virus core antigen; DAAs: Directacting antiviral drugs; SVR: Sustained virologic response; SOF: Sofosbuvir; DCV: Daclatasvir; RVN: Ribavirin

\section{Acknowledgements}

Not applicable.

Authors' contributions

AE contributed in the conception and design of the work and was the major contributor in writing, revision, and language polishing of the manuscript. GE contributed in performing the practical section of this work. ME, NE, and $M Z$ contributed in the collection of samples and interpretation of the clinical and laboratory data. EE contributed in the revision of the work and corrected and edited the manuscript. All authors have read and approved the final manuscript.

Funding

Not applicable. The study was fully non-funded from any organization.

Availability of data and materials

All data generated or analyzed during this study are included in this published article.

\section{Declarations}

Ethics approval and consent to participate

Approval was obtained from the Ethics Committee of Faculty of Medicine, Menoufia University (No. 2311/14-8-2018). Informed written consent was obtained from each participant before enrollment in the study.

\section{Consent for publication}

Not applicable.

\section{Competing interests}

The authors declare no competing interests.

\section{Author details}

${ }^{1}$ Department of Medical Microbiology and Immunology, Faculty of Medicine, Menoufia University, Shibin El Kom, Egypt. ²Department of Tropical Medicine, Faculty of Medicine, Menoufia University, Shibin El Kom, Egypt. ${ }^{3}$ Department of Clinical Biochemistry and Molecular Diagnostics, National Liver Institute, Menoufia University, Shibin El Kom, Egypt. ${ }^{4}$ Department of Hepatology and Gastroenterology, National Liver Institute, Menoufia University, Shibin El Kom, Egypt. 
Received: 3 September 2020 Accepted: 10 March 2021

Published online: 18 March 2021

\section{References}

1. Zhijuan Fan MS, Junfeng Liu MS, Wang F, Jingmin Liu BS, Xian Ding BS, Liu S (2019) HCV core antigen is a useful predictor during pegylated-interferon/ribavirin therapy in patients with hepatitis C virus genotype 1b. Medicine 98:10(e14795)

2. El-Ghitany EM (2019) Hepatitis C virus infection in Egypt: current situation and future perspective. J High Institute Public Health 49(1):1-9. https://doi. org/10.21608/jhiph.2019.29460

3. National Institutes of Health (2002) NIH consensus statement on management of hepatitis C. NIH Consens State Sci Statements 19(3):1-46

4. Kesli R, Polat H, Terz Y et al (2011) Comparison of a newly developed automated and quantitative hepatitis $\mathrm{C}$ virus ( $\mathrm{HCV}$ ) core antigen test with the HCV RNA assay for clinical usefulness in confirming anti-HCV results. J Clin Microbiol 49(12):4089-4093

5. Nguyen LT, Gray E, O'Leary A, Carr M, De Gascun CF (2016) The role of hepatitis C virus core antigen testing in the era of direct acting antiviral therapies: what we can learn from the protease inhibitors. PLoS One 11:e0163900

6. WHO Guidelines (2016) Guidelines for the screening care and treatment of persons with chronic hepatitis C infection: updated version. WHO Guidelines Approved by the Guidelines Review Committee, Geneva

7. Freiman $M$ et al (2016) Hepatitis C core antigen testing for diagnosis of hepatitis $C$ virus infection. A systematic review and meta-analysis. Ann. Intern. Med. 165(5):345-355. https://doi.org/10.7326/M16-0065

8. Lin SF, Tung SY, Wei KL, Chen CH, Hu TH, Shen CH, et al., (2020) Clinical utility of hepatitis $C$ virus core antigen assay in the monitoring of directacting antivirals for chronic hepatitis C.PLOS ONE https://doi.org/https://doi. org/10.1371/journal.pone.0229994; Marsh 2020.

9. Hezode C, Fontaine H, Dorival C et al (2014) Effectiveness of telaprevir or boceprevir in treatment-experienced patients with HCV genotype 1 infection and cirrhosis. Gastroenterology 147(1):132-142. https://doi.org/10.1053/j.gastro.2014.03.051

10. Chronic hepatitis $C$ virus infection: developing direct-acting antiviral drugs for treatment guidance for industry; U.S. Department of Health and Human Services Food and Drug Administration Center for Drug Evaluation and Research (CDER) November 2017; Clinical/Antimicrobial.

11. The American Association for the Study of Liver Diseases and the Infectious Diseases Society of America; AASLD \& IDSA HCV (2018) Guidance Panel. Hepatitis C guidance 2018 update: AASLD-IDSA recommendations for testing, managing, and treating hepatitis C virus infection. Clin Infect Dis 67:1477-1492

12. HCV treatment protocol in Egypt (Supreme Council and National treatment programme of Hepatitis C updated Treatment Protocol December 2019; NCCVH).

13. Esmat G, Raziky ME, Nabeel MM, Maher R, Zakaria Z (2016) Seroprevalence of HCV among Cairo University students in Egypt. J Med Virol 88(8):13841387. https://doi.org/10.1002/jmv.24469

14. European Association for the Study of the Liver (EASL): Recommendations on the treatment of HCV hepatitis C: management of hepatitis C. J Hepatol, (2018); 69: 461-511. Pmid:2965033

15. Soliman HA, Hozayen WG, Mahmoud AM, Abo Seif MA, Fayed NA (2015) Significance of the hepatitis $C$ virus core antigen testing as an alternative marker for hepatitis diagnosis in Egyptian patients. Eur Rev Med Pharmacol Sci 19(12):2240-2245

16. Wang L, Chen W, Xi W, Feng J, Dang P, Ma Y, Yu Y (2017) Utility of enzymelinked immunosorbent assays to test core antigen in the diagnosis and antiviral therapy management of hepatitis C virus infections. J Med Virol. 89(7):1235-1240. https://doi.org/10.1002/jmv.24754

17. Kuo YH, Chang KC, Wang JH, Tsai PS, Hung SF, Hung CH, Chen CH, Lu SN (2012) Is hepatitis $C$ virus core antigen an adequate marker for community screening? J Clin Microbiol 50:1989-1993

18. Alsiö A, Jannesson A, Langeland N, Pedersen C, Färkkilä M, Buhl MR, Mørch K, Westin J, Hellstrand K, Norkrans G et al (2012) Early quantification of HCV core antigen may help to determine the duration of therapy for chronic genotype 2 or 3 HCV infection. Eur J Clin Microbiol Infect Dis 31(7):16311635. https://doi.org/10.1007/s10096-011-1486-5

19. Park IY, Lee JH, Kim BS, Kim DY, Han KH, Kim HS (2010) New automated hepatitis $C$ virus (HCV) core antigen assay as an alternative to real-time PCR for HCV RNA quantification. J Clin Microbiol 48:2253-2256

20. Kim MN, Kim HS, Kyung Kim JK, Kyung Kim B, Kim SU, Park JY, Kim DY, HoonAhn S, Han KH (2016) Clinical utility of a new automated hepatitis C virus core antigen assay for prediction of treatment response in patients with chronic hepatitis C. J Korean Med Sci 31(9):1431-1437. https://doi.org/1 0.3346/jkms.2016.31.9.1431
21. Thong VD, Akkarathamrongsin S, Avihingsanon A, Theamboonlers A, Poovorawan Y, Tangkijvanich P (2015) The correlation between hepatitis C core antigen and hepatitis C virus RNA levels with respect to human immunodeficiency virus status, hepatitis $C$ virus genotype and interferon-lambda-4 polymorphism. Intervirology 58(2):73-79. https:/doi.org/10.1159/000370070

22. Seme K, Poljak M, Babic DZ, Mocilnik T, Vince A (2005) The role of core antigen detection in management of hepatitis C: a critical review. J. Clin. Virol. 32(2):92-101. https://doi.org/10.1016/j.jcv.2004.10.005

23. Pérez-García A, Aguinaga A, Navascués A, Castilla J and Ezpeleta C (2019) Hepatitis $C$ core antigen: diagnosis and monitoring of patients infected with hepatitis C virus. Int J Infect Dis: Volume 89, December Pages 131-136.

24. Lamoury FMJ, Soker A, Martinez D, Hajarizadeh B, Cunningham EB, Cunningham $P$ et al., (2017) Hepatitis C virus core antigen: a simplified treatment monitoring tool, including for post-treatment relapse. J Clin Virol; Volume 92, July, Pages 32-38.

25. Sayed MM, El-Shafie Al, Hilal AF, Abdelsattar HA (2017) Can hepatitis C virus core antigen be used a reliable marker of viral load for hepatitis $C$ virus infection in genotype 4? Egyptian liver journal.7 (1 and 2); 1-4.

26. Nouh MAE, Mohamed GE, Mohammed AMS, Ahmed REG (2020) Cost-effectiveness of HCV core antigen versus PCR for monitoring treatment response in DAAStreated Egyptian patients. Afro-Egypt J Infect Endem Dis 10(2):174-182

27. Rockstroh JK, Jordan J, Feld J, Chevaliez S, Chengd K, Wedemeyere H, Sarrazin C, Maasoumy B, Hermand C, Hackett J, Daniel EC, Dawsond GJ, Clohertyd G, Pawlotsky JM (2017) HCV core antigen as an alternate test to HCV RNA for assessment of virologic responses to all-oral, interferon-free treatment in HCVgenotype 1 infected patients. J Virol Methods 245:14-18

28. Rutter $K$, Stättermayer AF, Ferenci $P$, Beinhardt S, Scherzer TM, StrassI R, Steindl-Munda P, Trauner M, Hofer H (2013) 896 Successful HCV eradication due to antiviral therapy is associated with improved long term outcome of patients with chronic hepatitis C. J Hepatol 1(58):S369

29. Pischke S, Polywka S, Proske VM, Lang M, Jordan S, Nashan B, Lohse AW, Sterneck M (2016) Course of hepatitis C virus (HCV) RNA and HCV core antigen testing are predictors for reaching sustained virologic response in liver transplant recipients undergoing sofosbuvir treatment in a real-life setting. Transplant Infect Dis 18(1):141-145. https://doi.org/10.1111/tid.12475

30. Aghemo A, Degasperi E, De Nicola S, Bono P, Orlandi A, D'Ambrosio R, Soffredini R, Perbellini R, Lunghi G, Colombo M (2016) Quantification of core antigen monitors efficacy of direct-acting antiviral agents in patients with chronic hepatitis C virus infection. Clin Gastroenterol Hepatol 14(9):13311336. https://doi.org/10.1016/j.cgh.2016.03.035

31. Arboledas JC, Guerrero IP, Rodríguez MJ, Martos ET, Pérez AB, León CC, Sánchez JF, Prieto MD, Porcuna NC, Mochón MD, Macías J (2017) Hepatitis C virus core antigen in the management of patients treated with new direct-acting antivirals. Diagnostic Microbiol Infect Dis 89(1):29-34. https:/doi.org/10.1016/j.diagmicrobio.2017.06.006

32. Daniel HDJ, Vivekanandan P, Raghuraman S, Sridharan G, Chandy GM, Abraham P (2007) Significance of the hepatitis C virus (HCV) core antigen as an alternative plasma marker of active HCV infection. Indian J. Med. Microbiol. 25(1):37-42. https://doi.org/10.4103/0255-0857.31060

33. Ergünay K, Şener B, Alp A, Karakaya J, Hasçelik G (2011) Utility of a commercial quantitative hepatitis $C$ virus core antigen assay in a diagnostic laboratory setting. Diagnostic Microbiol Infect Dis 70(4):486-491. https://doi. org/10.1016/j.diagmicrobio.2011.04.011

34. Kotb DN, Esmail MA, Abdelwahab SF, Abdel Hamid M (2017) Correlation between hepatitis $C$ viral load and hepatitis C core antigenaemia among Egyptians. EMHJ 23(4):280-286. https://doi.org/10.26719/2017.23.4.280

35. Demircili ME, Ozdemir M, Feyzioglu B, Baysal B (2016) The efficiency of hepatitis $C$ virus core antigen test in the diagnosis of hepatitis $C$ infection. Viral Hepatitis J 22(1):18-22. https://doi.org/10.4274/vhd.78300

36. Miedouge M, Saune K, Kamar N, Rieu M, Rostaing L, Izopet J (2010) Analytical evaluation of HCV core antigen and interest for HCV screening in haemodialysis patients. J Clin Virol. 48:18-21

37. Medici MC, Furlini G, Rodella A, Fuertes A, Monachetti A, Calderaro A, Galli S, Terlenghi L, Olivares M, Bagnarelli P, Costantini A (2011) Hepatitis C virus core antigen: analytical performances, correlation with viremia and potential applications of a quantitative, automated immunoassay. J Clin Virol 51(4): 264-269. https://doi.org/10.1016/j.jcv.2011.05.003

\section{Publisher's Note}

Springer Nature remains neutral with regard to jurisdictional claims in published maps and institutional affiliations. 